\title{
PENERAPAN TEKNIK SELF MANAGEMENT UNTUK MEREDUKSI AGRESIFITAS REMAJA
}

\author{
Halimatus Sa'diyah * \\ halimatuss714@gmail.com \\ Muh. Chotim** \\ muh_chotim@yahoo.co.id \\ Diana Ariswanti Triningtyas** \\ dietyas61@yahoo.co.id
}

\begin{abstract}
Abstrak
Agresifitas merupakan suatu perilaku fisik maupun verbal, yang bertujuan menyakiti orang lain. Seperti: memukul, menendang, mengolok-olok atau berkata kasar. Hasil pengamatan sementara, yang dilakukan peneliti di SMP Negeri 2 Geger Kabupaten Madiun, ditemukan sejumlah data (siswa kelas VII) yang tergolong usia remaja sering terlibat perkelahian, memukul, menendang, mengolok-olok atau dan berkata kasar. Hal yang demikian menunjukkan adanya (berprilaku agresif) yang perlu diteliti lebih mendalam, melalui penerapan teknik self management, dengan tujuan dapat mereduksi agresifitas remaja (siswa). Penerapan teknik Self management ini diharapkan dapat membantu remaja (siswa) mampu memahami, mengatur dan mengendalikan perilakunya sendiri.

Penelitian ini menggunakan metode eksperimen, dengan desain penelitian One- Group Pretest- Posttest Design, dengan populasi dan sampel yang berjumlah sama (10 orang) yang memiliki kecenderungan berprilaku agresif. Sesuai dengan maksud dan tujuan penelitian, sampel diambil dengan teknik purposive sampling, yaitu 10 remaja (siswa) kelas VII yang memiliki kecenderungan agresifitas. Teknik pengumpulan data menggunakan angket, dan analisis data menggunakan uji t (t-score).

Hasil analisis data, menunjukkan, bahwa harga $\mathrm{t}$ hitung $\left(\mathrm{t}_{\text {score }}\right)>\mathrm{t}$ tabel $(=6,778>1,833)$ yang berararti signifikan. Jadi simpulannya: "Penerapan teknik self management dapat mereduksi agresifitas remaja".
\end{abstract}

Kata Kunci: Teknik Self Management, Agresifitas Remaja

* Halimatus Sa'diyah adalah mahasiswa program studi Bimbingan dan Konseling IKIP PGRI Madiun

** Muh Chotim dan Diana Ariswanti Triningtyas adalah dosen program studi Bimbingan dan Konseling IKIP PGRI Madiun 


\section{PENDAHULUAN}

Masa remaja merupakan masa dimana seseorang berada diantara masa anak-anak dan dewasa. Remaja sering kali dikenal dengan fase mencari jati diri. Pada masa ini, remaja ingin menemukan dan menunjukkan siapa dirinya, agar mendapatkan pengakuan dari temanteman dan lingkungan sosialnya. Masa remaja juga dikenal sebagai masa badai topan, karena pada masa ini remaja (dalam tugas perkembangannya) belum mampu menguasai dan memfungsikan kemampuan mereka., baik kemampuan fisik maupun kemampuan psikisnya secara maksimal. Kesulitan-kesulitan yang dihadapi remaja dalam mencapai tugas perkembangan menyebabkan terhambatnya perkembangan emosi dan perilaku sosial yang diantaranya diwujudkan dalam bentuk perilaku agresif (Septiana, dkk,. 2013: 218). Sejalan dengan penelitian yang dilakukan oleh John Dollard dan Neal Miller (dalam Sarwono \& Meinarno, 2009: 150), menunjukkan bahwa tidak tercapainya keinginan menyebabkan ketidaknyamanan yang menimbulkan adanya kemarahan kemudian berubah menjadi perilaku agresif.

Agresifitas atau perilaku agresif menurut Myers (2012:69) merupakan suatu perilaku fisik maupun verbal yang bertujuan menyakiti orang lain. Harris (dalam Thalib, 2010:213) menyebutkan perilaku agresif dapat ditunjukkan melalui berbagai bentuk perilaku, seperti menyerang orang lain (memukul, menampar, menendang, menggigit), mengancam secara fisik atau verbal, melecehkan orang lain (mengejek, berteriak, berkata kasar), bersikap tidak sopan dan memaksa untuk memiliki bendabenda orang lain yang bukan miliknya. Perilaku tersebut sangat mengganggu dan merugikan perkembangan dirinya maupun orang-orang di lingkungan sekitarnya.

Perilaku agresif yang sering dilakukan menyebabkan remaja menjadi terbiasa bertindak kasar kepada teman-temannya apabila ada keinginan yang tidak tercapai. Dari pengamatan yang dilakukan peneliti, di SMP Negeri 2 Geger, ditemukan sejumlah siswa, terutama siswa kelas VII yang termasuk dalam usia remaja sering terlibat perkelahian. Mereka mudah memukul, berkata kasar, mengejek dan mengolo-olok teman di luar kelas maupun di dalam kelas ketika pelajaran berlangsung. Siswa tersebut sulit mengendalikan diri, untuk tidak berprilaku agresif (kasar), meskipun sudah berulang kali diperingatkan dan diberi sanksi oleh guru BK, ataupun guru yang lain.

Sementara, tindakan yang diberikan oleh guru SMP Negeri 2 Geger untuk mengurangi agresifitas siswa tersebut berupa peringatan dan pemberian sanksi. Pemberian sanksi hanya membuat siswa jera pada saat 
itu, namun di saat yang lain, agresifitas terulang kembali. Hal yang demikian ini diperlukan adanya kesadaran diri dan pengelolaan diri (self management) yang baik dari mereka sendiri (remaja), agar mereka mampu mengendalikan emosi dan mengatur diri mereka sendiri, tidak berprilaku kasar, berbicara kotor atau berprilaku agresif.

Self management merupakan salah satu teknik dalam konseling behavior, yang mempelajari tingkah laku (individu manusia) yang bertujuan merubah perilaku maladaptif menjadi adaptif. Self management adalah suatu prosedur dimana individu mengatur perilakunya sendiri. Dalam penerapan teknik self management tanggung jawab keberhasilan konseling berada di tangan konseli. Konselor berperan sebagai pencetus gagasan, fasilitator yang membantu merancang program serta motivator bagi konseli (Sukadji dalam Komalasari, dkk., 2011: 181). Untuk itu diperlukan adanya bantuan konseling dengan teknik self management (pengaturan dan pengelolaan diri) terhadap para remaja (siswa kelas VII) tersebut, agar mereka mampu memahami, mengatur dan mengendalikan diri mereka sendiri, dapat merubah perilaku maladaptif menjadi adaptif, tidak berprilaku kasar (baik secara fisik ataupun verbal). Pada akhirnya remaja mampu mencapai tugas perkembangannya secara optimal, dan terhindar dari agresifitas fisik maupun agresifitas verbal (baik secara langsung maupun tidak langsung).

Pendekatan behavioral atau dikenal juga dengan modifikasi perilaku yaitu pendekatan yang mempelajari tingkah laku manusia, bertujuan untuk merubah perilaku maladaptif menjadi perilaku adaptif. Konseling behavioral memiliki asumsi dasar bahwa setiap tingkah laku dapat dipelajari; tingkah laku lama dapat diganti dengan tingkah laku baru dan manusia memiliki potensi untuk berperilaku baik atau buruk, tepat atau salah. Selain itu, manusia dipandang sebagai individu yang mampu melakukan refleksi atas tingkah lakunya sendiri, mengatur serta dapat mengontrol perilakunya dan dapat belajar tingkah laku baru atau dapat dipengaruhi perilaku orang lain (Walker \& Shea dalam Komalasari,dkk., 2011:141).

Terdapat beberapa teknik dalam konseling behavior, namun pada penelitian ini hanya ada satu teknik konseling behavior yang digunakan dalam penelitian ini, yaitu teknik self management.

Sukadji (dalam Komalasari, dkk., 2011: 180) Self management atau pengelolaan diri adalah suatu prosedur dimana individu mengatur perilakunya sendiri. Cormier \& Cormier (dalam Alamri, 2015) Self management adalah suatu strategi pengubahan perilaku yang dalam prosesnya konseli mengarahkan 
perubahan perilakunya sendiri dengan suatu teknik atau kombinasi teknik terapeutik.

Suwardani, dkk. mengartikan self management adalah teknik menata perilaku individu yang bertujuan untuk mengarahkan dan mengelola dirinya agar dapat mencapai kemandirian dan hidupnya berjalan dengan produktif.

Soekadji (dalam Purwanta, 2012: 181-183), ada empat tahap untuk menerapkan teknik self management ini, yaitu: (a). Tahap monitor atau observasi diri, pada tahap ini subjek atau siswa dengan sengaja mengamati perilakunya sendiri dan mencatat jenis, waktu, durasi perilaku yang ada pada diri subjek yang akan dimodifikasi. (b) Mengatur lingkungan, pada tahap ini lingkungan perlu diatur, sehingga dapat mengurangi atau meniadakan perilaku-perilaku yang memungkinkan mendapatkan pengukuhan segera. (c)Tahap evaluasi diri, pada tahap ini subjek membandingkan apa yang tercatat sebagai kenyataan dengan apa yang seharusnya dilakukan. Catatan data observasi perilaku yang teratur sangat penting untuk mengevaluasi efisiensi dan efektivitas program. Bila evaluasi data menunjukkan bahwa program tidak berhasil, maka perlu ditinjau kembali. (d)Tahap pemberian pengukuhan, penghapusan atau hukuman. Pada tahap ini diperlukan kemauan diri yang kuat untuk menentukan dan memilih pengukuhan apa yang perlu segera dihadirkan atau perilaku mana yang segera dihapus dan bahkan hukuman diri sendiri apa yang harus segera diterapkan. Melalui teknik self management dengan empat tahap itulah agresifitas remaja diharapkan berubah.

Myers (2012: 69) agresifitas atau perilaku agresif merupakan suatu perilaku fisik maupun verbal yang bertujuan untuk menyakiti orang lain.

Berkowitz, et al (dalam Thalib, 2010: 212) mendefinisikan perilaku agresif sebagai perilaku yang secara aktual menimbulkan dampak negatif baik secara fisik, psikis, sosial, integritas, objek atau lingkungan.

Pada penelitian ini yang dimaksud agresifitas remaja adalah perilaku remaja yang ditunjukkan dengan cara menyakiti atau menyerang orang lain secara fisik atau verbal dan menimbulkan dampak negatif terhadap fisik, psikis, sosial dan lingkungan.

Dilihat dari macamnya terdapat beberapa macam prilaku agresif, diantaranya adalah:

a. Agresif secara fisik atau verbal (menyakiti secara fisik atau menyerang dengan kata-kata).

b. Agresif secara aktif atau pasif (kegiatan yang bermaksud jahat dan kegagalan untuk memainkan peran).

c. Agresif secara langsung atau tidak langsung (agresi secara berhadap- 
hadapan atau tidak ( Jahja ,2011: 383-384)

Ursin dan Olff (dalamThalib, 2010: 213) membedakan perilaku agresif menjadi agresifitas fisik dan agresifitas verbal.

Harris (dalam Thalib, 2010: 213) menyebutkan bentuk-bentuk perilaku agresif, yaitu: (a) Menyerang orang lain, seperti memukul, menampar, menendang, menggigit.. Mengancam secara fisik atau verbal. (c) Melecehkan orang lain seperti mengejek, berteriak, berkata kasar.(d) Bersikap tidak sopan.(e) Memaksa untuk memiliki bendabenda orang lain yang bukan miliknya. Ditinjau secara umum, faktor penyebab perilaku agresif dibedakan menjadi dua, yaitu faktor personal dan sosial (Ursin dan Olff , dalam Thalib, 2010: 213). Faktor personal lebih merupakan sifat dasar (genetik), sedangkan faktor sosial merupakan faktor eksternal atau faktor yang bersumber dari luar individu yang berwujud manusia dan representasinya (sebuah proses sosial yang berhubungan dengan pola hidup dan budaya masyarakat yang memungkinkan terjadinya sebuah perubahan konsep diri dalam bentuk yang konkrit).

Sarwono dan Meinarno (2009: 152) penyebab agresi pada manusia adalah sosial, personal, kebudayaan dan media massa.

Sedangkan Miller (dalam Thalib, 2010: 214) menyebutkan adanya empat faktor penting yang dapat mempengaruhi agresifitas, yaitu: (a)Tekanan lingkungan menyebabkan ketegangan timbul. (b)Tekanan lingkungan menyebabkan rangsang terlampau banyak, sehingga orang kewalahan dan tidak mampu lagi untuk memproses informasi secara efektif. (c) Tekanan-tekanan bercampur dengan perilaku, menimbulkan frustasi dan perasaan kehilangan control. (d) Tekanan-tekanan membuat jengkel, merasa terganggu dan merasa tidak enak.

\section{METODE PENELITIAN}

Metode yang digunakan dalam penelitian ini adalah metode eksperimen. Metode eksperimen adalah metode penelitian yang digunakan untuk mencari pengaruh perlakuan tertentu terhadap yang lain dalam kondisi yang terkendalikan (Sugiono 2013:72). Metode ini digunakan untuk mengetahui pengaruh atau perbedaan (prilaku) antara sebelum pemberian perlakuan dengan sesudah pemberian perlakuan pada suatu kelompok.

Dalam penelitian ini, diterapkan desain Pra-eksperimental (PreExperimental Design) dengan bentuk one-group pretest dan one group postest. Dalam desain ini data dikumpulkan menggunakan angket yang disebarkan sebelum eksperimen (disebut pre-test) dan sesudah eksperimen (disebut pos-test).

Populasi pada penelitian ini yaitu siswa kelas VII SMP Negeri 2 
Geger Kabupaten Madiun yang berprilaku agresif, sebayak 10 orang.

Karena populasi berdasarkan data yang ada pada konselor sekolah, siswa yang berprilaku agresif hanya sebanyak 10 orang, , maka teknik pengambilan sampel dalam penelitian ini menggunakan teknik purposive sampling, yaitu sampel diambil sesuai maksud dan tujuan penelitian ( artinya 10 orang (siswa) yang berprilaku agresif tersebut, semuanya dijadikan sampel) atau istilah lain menggunakan sampel jenuh.

Pengumpulan data agresifitas remaja ( baik data sebelum maupun data sesudah diterapkan teknik self management) menggunakan instrumen angket, yaitu angket langsung yang bersifat tertutup. Sugiyono (2013:142) angket atau kuesioner adalah teknik pengumpulan data yang dilakukan dengan cara memberi seperangkat pertanyaan atau pernyataan tertulis kepada responden untuk dijawabnya.. Angket langsung artinya: angket tersebut diberikan dan dijawab langsung oleh responden itu sendiri yang menjadi sasaran dalam penelitian. Angket bersifat tertutup artinya responden tinggal memilih alternatif jawaban yang sudah tersedia.

Sehubungan dengan uji validitas, peneliti menggunakan teknik statistik dengan koefisien korelasi product moment. Dengan rumus sebagai berikut:

$$
\mathrm{r}_{\mathrm{xy}}=\frac{N \sum X Y-\left(\sum X\right)\left(\sum Y\right)}{\sqrt{\left[N \sum X^{2}-\left(\sum X\right)^{2}\right)\left(N \sum Y^{2}-\left(\sum Y\right)^{2}\right]}}
$$

Keterangan:

$$
\begin{aligned}
& r_{x y}=\text { Koefisien korelasi antara } \mathrm{X} \text { dan } \mathrm{Y} \\
& \sum \mathrm{X}=\text { Jumlah skor item } \\
& \sum \mathrm{Y}=\text { Jumlah skor total } \\
& \mathrm{N}=\text { Banyaknya subyek }
\end{aligned}
$$

Kriteria validitas, setelah $r_{\text {hitung }}$ ditemukan kemudian dikonsultasikan dengan $r_{\text {tabel }}$ dalam taraf signifikan 5\%. Jika $r_{\text {hitung }} \geq r_{\text {tabel }}(0,444)$ maka item dinyatakan valid. Dari hasil perhitungan sebanyak 20 item semuanya dinyatakan signifikan, berarti instrument angket valid

Sedangkan untuk uji reliabilitas angket (uji kestabilan angket) menggunakan rumus alpha, yaitu: 


$$
r_{11}=\left\{\frac{k}{k-1}\right\}\left\{1-\frac{\sum \sigma_{b}^{2}}{\sigma_{t}^{2}}\right\}
$$

Keterangan:

$$
\begin{array}{ll}
\mathrm{r}_{11} & =\text { Reliabilitas instrument } \\
\mathrm{k} & =\text { Banyaknya butir pernyataan atau banyaknya soal } \\
\sum \sigma_{b}^{2} & =\text { Jumlah varians butir } \\
\sigma_{t}^{2} & =\text { Varians total }
\end{array}
$$

Kriteria yang digunakan, setelah
$\mathrm{r}_{\text {hitung ditemukan kemudian }}$ dikonsultasikan dengan Nilai Croumbach Alpha $(0,6)$ dalam taraf signifikansi 5\%. Ketentuan, jika $r_{\text {hitung }} \geq \operatorname{NCA}(0,6)$ dalam taraf signifikansi $5 \%$, maka instrumen dinyatakan signifikan, yang berarti reliabel, dan jika sebaliknya $r_{\text {hitung }}<$ NCA $(0,6)$ maka instrumen dinyatakan tidak signifikan, berarti instrumen angket tidak reliabel". Adapun hasil uji releabilitas angket pada penelitian ini dinyatakan releabel. Karena instrumen angket dinyatakan valid dan reliabel, maka instrumen angket tersebut dapat digunakan untuk mengumpulkan data agresifitas remaja.

Sedangkan untuk uji hipotesis pada penelitian ini menggunakan uji statistik, dengan uji $\mathrm{t}$ ( $t$-score) dengan rumus sebagai berikut:

$$
t=\frac{M d}{\sqrt{\frac{\sum X^{2} d}{N(N-1)}}}
$$

Keterangan:

$$
\begin{aligned}
\mathrm{Md}= & \text { Mean dari perbedaan } \\
& \text { pretest dengan postest } \\
\mathrm{Xd}= & \text { Deviasi masing-masing } \\
& \text { subjek }(\mathrm{d}-\mathrm{Md})
\end{aligned}
$$

$$
\begin{array}{ll}
\sum \mathrm{X}^{2} \mathrm{~d} & =\text { Jumlah kuadrat deviasi } \\
\mathrm{N} & =\text { Subjek pada sampel } \\
\mathrm{d} . \mathrm{b} & =\text { Ditentukan dengan N-1 }
\end{array}
$$

\section{HASIL PENELITIAN}

\section{Deskripsi Data}

Berdasarkan hasil analisis statistic, data agresifitas remaja yang dihitung secara manual dapat dideskrpsikan atau disajikan sebagai berikut:

\section{Deskripsi Data Agresifitas Sebelum Penerapan Teknik Self Management.}

Data Agresifitas remaja kelas VII sebelum penerapan teknik self management diperoleh melalui pengisian angket (Pre-test) sejumlah 20 item pada sampel sebanyak 10 remaja, siswa kelas VII yang memiliki kecenderungan berperilaku agresif. Dengan rentang skor 46-65 diperoleh perhitungan sebagai berikut: Skor terendah 46, skor tertinggi 65 , mean atau nilai rata-rata 60, median atau nilai tengah 57, modus atau nilai yang sering muncul 59, standart deviasi 8,62. 
Mengingat data hasil penyebaran angket tersebut akan disajikan dalam bentuk tabel dan grafik, maka data terlebih dahulu ditabulasikan dan selanjutnya dilakukan perhitungan jarak pengukuran atau mencari Range (R) dengan cara batas atas nyata dikurangi batas bawah nyata
$(65,5-45,5=20) . \quad$ Kemudian menghitung lebar kelas (i), ditentukan interval kelas 4, maka lebar kelas (i) adalah (20:4=5).

Berdasarkan hasil perhitungan tersebut diperoleh tabel distribusi frekuensi data sebagai berikut:

\section{Tabel 1 Distribusi Frekuensi Data Agresifitas Remaja Sebelum Penerapan Teknik Self Management.}

\begin{tabular}{cccc}
\hline No & $\begin{array}{c}\text { Interval } \\
\text { Nilai }\end{array}$ & $\begin{array}{c}\text { Nilai } \\
\text { tengah } \\
(\mathbf{X i})\end{array}$ & $\begin{array}{c}\text { Frekuensi } \\
(\mathbf{f})\end{array}$ \\
\hline 1 & $61-65$ & 63 & 2 \\
\hline 2 & $56-60$ & 68 & 4 \\
\hline 3 & $51-55$ & 53 & 1 \\
\hline 4 & $46-50$ & 48 & 3 \\
\hline Jumlah $\left(\sum\right)$ & & $\mathbf{1 0}$ \\
\hline
\end{tabular}

Berdasarkan tabel 1 tersebut, data dapat disajikan ke dalam bentuk gambar (histogram) yaitu Gambar 1 data agresifitas sebelum penerapan teknik self management yaitu:

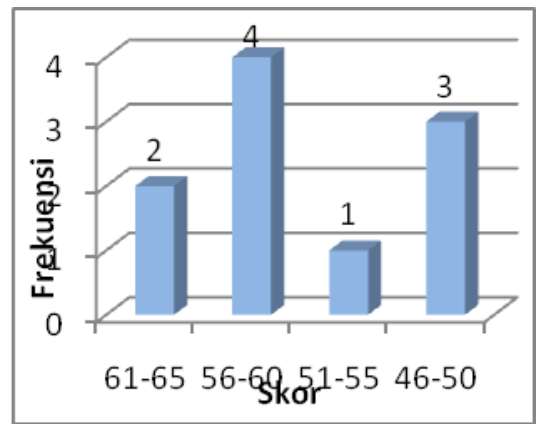

Gambar 1. Data Agresifitas Remaja Sebelum Penerapan Teknik Self Management.

Berdasarkan ganbar 1, data agresifitas sebelum penerapan teknik self management di atas, dapat diketahui bahwa skor agresifitas tertinggi berada pada rentang skor
61-65 dengan jumlah frekuensi 2, sedangkan skor agresifitas terendah berada pada rentang skor 46-50 dengan jumlah frekuensi 3. 
2. Deskripsi Data Agresifitas Sesudah Penerapan Teknik Self Management

Data Agresifitas remaja kelas VII sesudah penerapan teknik self management diperoleh melalui penyebaran angket (post-test) sejumlah 20 item pada sampel sebanyak 10 remaja, siswa kelas VII yang memiliki kecenderungan perilaku agresif dengan rentang skor 39-58, diperoleh perhitungan sebagai berikut: Skor terendah 39, skor tertinggi 58, mean atau nilai rata-rata 50 , median atau nilai tengah 51, modus atau nilai yang sering muncul 51 dan 56, standar deviasi 5,83 .
Mengingat data hasil penyebaran angket tersebut akan disajikan dalam bentuk tabel dan grafik, maka data terlebih dahulu ditabulasikan. Selanjutnya dilakukan perhitungan jarak pengukuran atau mencari Range (R) dengan cara batas atas nyata dikurangi batas bawah nyata $(58,5-38,5=20)$. Kemudian menghitung lebar kelas (i), ditentukan interval kelas 4, maka lebar kelas (i) adalah $(20: 4=5)$.

Dari perhitungan tersebut diperoleh tabel distribusi frekuensi sebagai berikut:

Tabel 2. Distribusi Frekuensi Data Agresifitas Remaja Sesudah Penerapan Teknik Self Management.

\begin{tabular}{|c|c|c|c|}
\hline No & Interval Nilai & Nilai tengah (Xi) & Frekuensi (f) \\
\hline 1 & $54-58$ & 56 & 4 \\
\hline 2 & $49-53$ & 51 & 2 \\
\hline 3 & $44-48$ & 46 & 2 \\
\hline 4 & $39-43$ & 41 & 2 \\
\hline & Jumlah ( $\Sigma$ & & $\mathbf{1 0}$ \\
\hline
\end{tabular}

Berdasarkan tabel 2 di atas, data agresifitas remaja sesudah penerapan teknik self management dapat disajikan pada gambar 2. di bawah ini: 


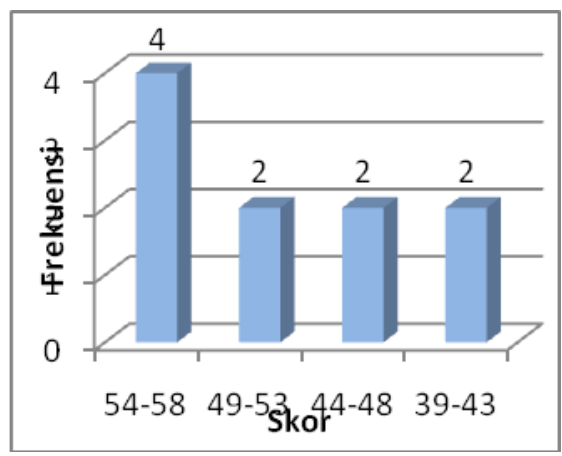

Gambar 2. Data Agresifitas Remaja Sesudah Penerapan

Teknik Self Management.

Berdasarkan gamnar 2 dat agresifitas remaja sesudah penerapan teknik self management pada gambar di atas, dapat diketahui, bahwa skor agresifitas tertinggi berada pada rentang skor 54-58 dengan jumlah frekuensi 4, sedangkan skor agresifitas terendah berada pada rentang skor 39-43 dengan jumlah frekuensi 2 .

\section{Hasil Pengujian Hipotesis dan Pembahasan}

Berdasarkan analisis data yang dihitung dengan rumus $\mathrm{t}$-score, diperoleh harga $\mathrm{t}_{\text {hitung }}\left(\mathrm{t}_{\text {score }}\right)$ sebesar 6,778. kemudian $t$ hitung dikonsultasikan dengan $\mathrm{t}_{\text {tabel. }}$. Harga $\mathrm{t}$ tabel dengan d.b 9 dan taraf signifikansi $5 \%$ adalah 1,833 . Karena $\mathrm{r}_{\text {hitung }}(6,778)>\mathrm{r}_{\text {tabel }}(1,833)$ dalam taraf signifikansi $5 \%$, maka berarti signifikan.

Berdasarkan hasil uji hipotesis yang signifikan itu, maka hipotesis yang berbunyi "Penerapan teknik self management dapat mereduksi agresifitas remaja (siswa) kelas VII
SMPN 2 Geger Kabupaten Madiun”, dapat diterima (dalam arti benar).

Diterimanya hipotesis tersebut didukung oleh hasil analisis data yang menunjukkan adanya penurunan nilai rata-rata skori sebelum penerapan (pre-test) tinggi dan nilai rata-rata skor sesudah penerapan (post-test) rendah. Disamping itu juga didukung oleh data yang dimiliki oleh konselor sekolah, bahwa sebelum pemberian treatment diketahui sebagian remaja (siswa) kelas VII memiliki agresifitas tinggi, tetapi setelah mendapatkan treatment dengan teknik self management yang diberikan melalui layanan konseling kelompok terjadi perubahan yang lebih baik, yaitu ada penurunan skor agresifitas menjadi rendah.. Seperti: berkurangnya perilaku mudah memukul teman (orang lain), mengumpat ketika marah, dan lainlain. Penurunan skor agresifitas pada subjek berbeda-beda, hal ini karena adanya perbedaan karakteristik dan perbedaan faktor yang mendorong individu untuk berperilaku agresif. 
Dari penurunan skor tersebut di atas, maka dapat dikatakan bahwa penerapan teknik self management dapat mereduksi agresifitas remaja kelas VII SMP Negeri 2 Geger Kabupeten Madiun.

\section{SIMPULAN DAN SARAN}

Bertolak dari hasil analisis data dan pembahasan, maka dapat diambil simpulan, bahwa:" Penerapan teknik Self Management dapat mereduksi agresifitas remaja kelas VII SMP Negeri 2 Geger Kabupaten Madiun".

Atas dasar simpulan tersebut, maka dapat dikemukakan beberapa saran sebagai berikut: (a) Untuk kehidupan praktis sehari-hari (konselor sekolah), teknik self management dapat dimanfaatkan atau dan diterapkan melalui konseling individu atau kelompok untuk mereduksi atau meminimalisir berbagai prilaku siswa yang tidak kita inginkan (negatif). Seperti: kecenderungan membolos, bullying, narkoba, menunda-nunda pekerjaan dan lain sebagainya.. (b) Untuk pengembangan ilmu pengetahuan (bagi peneliti lain) dapat mencoba menerapkan teknik self management ini untuk meneliti permasalahanpermasalahan yang lebih jauh/ luas dan lebih mendalam dengan berkolaborasi dengan peneliti lain yang seprofesi atau lain profesi yang sama-sama ingin mendalami permasalahan-permasalahan tersebut dengan ruang lingkup yang lebih luas dan dalam, dengan subjek dan durasi waktu yang berbeda-beda, sehingga mendapatkan hasil yang lebih memuaskan.

\section{DAFTAR PUSTAKA}

Edi Purwanta. 2012. Modifikasi

Perilaku Alternatif Penanganan

Anak Berkebutuhan

Khusus.Yogyakarta: Pustaka

Belajar.

Mohammad Ali,dan Mohammad Asrori. 2014. Psikologi Remaja Perkembangan Peserta Didik. Jakarta: Bumi Aksara.

Myers G, David.. 2012. Psikologi Sosial. Jakarta: Salemba Humanika.

Ni Pipi Suwardani, dkk. 2014. Penerapan Konselling Behavioral dengan Teknik Self Management Untuk Meningkatkan Konsep Diri Siswa Kelas VIII B3 SMP Negeri 4 Singaraja. E-jurnal Undiksa Jurusan Bimbingan Konseling (Online), jilid 2, No. 1, (http://ejournal.undiksha.ac.id/ind ex.php/JJBK/article/download/37 50/3005, diunduh tanggal 09 Maret 2016).

Nurdjana Alamri. 2015. Layanan Bimbingan Kelompk dengan Teknik Self Management untuk Mengurangi Perilaku Terlambat Sekolah (Studi Pada Siswa Kelas $\mathrm{X}$ SMA 1 Gebog Tahun 2014/2015). Jurnal Konseling Gusjigang (online), jilid 01, No. 01 ,

(http://jurnal.umk.ac.id/index.php/ gusjigang/article/view/259/258, diunduh tanggal 09 Maret 2016). 
78 Jurnal Ilmiah Counsellia, Volume 6 No. 2, November 2016 : 67 - 78

Sarlito Sarwono dan Eko A Meinarno. 2009. Psikologi Sosial. Jakarta: Salemba Humanika.

Septina Yunika Sari, dkk. 2013. Penggunaan Konseling Kelompok Realita untuk Menurunkan Perilaku Agresif Siswa di SMP PGRI 1 Karang Empat Surabaya. Jurnal BK UNESA (Online), jilid 03, No. 01, (http://ejournal.unesa.ac.id/index. php/jurnal-bkunesa/article/view/3338/5614, diunduh tanggal 10 Maret 2016).

Sugiono. 2013. Metode Penelitian Kuantitatif Kualitatif dan $R \& D$. Bandung: CV. Alfabeta.
Suharsimi Arikunto. 2013. Prosedur Penelitian Suatu Pendekatan Praktik. Jakarta: Rineka Cipta.

Syamsul Bachri Thalib. 2010. Psikologi Pendidikan Berbasis Analisis Empiris Aplikatif. Jakarta: Kencana Prenada Media Group.

Yudrik Jahja.. 2011. Psikolohgi Perkembangan. Jakarta: Prenada Media Goup.

Zulkifli. 2006. Psikologi Perkembangan. Bandung: Remaja Rosdakarya. 